\title{
Supplementation of Heit-Chrose Into Dairy Cow Feed Improves in Vitro Rumen Fermentation
}

\author{
Caribu Hadi Prayitno \\ Faculty of Animal Science, Jenderal Soedirman University, Jl. Dr. Soeparno, Karangwangkal, Purwokerto 53123 \\ Phone: +62-281638792; Facsimile: +62-281-638792, Indonesia \\ *Corresponding author email: caribu_prayitno@yahoo.co.id
}

\begin{abstract}
The objective of the study was to evaluate the effect of Heit-Chrose (HC) supplementation using in vitro method on ruminal fermentation of dairy cattle. $\mathrm{HC}$ is a feed supplement derived from garlic containing allicin, saponin and organic minerals $(\mathrm{Se}, \mathrm{Cr}$ and $\mathrm{Zn}$ ). This research was conducted using completely randomized design, with 6 treatments and 4 replications. The treatments were 1$) . \mathrm{C}=$ dairy cattle feed (CP $15.38 \%$, CF $23.38 \%$, TDN 61.26\%); 2). HC-0 = C+ organic minerals (0.3 ppm Se $+0.15 \mathrm{ppm} \mathrm{Cr}+40 \mathrm{ppm}$ Zinclysinat) +0 ppm of HC; 3). HC-15 = C +15 ppm HC; 4). HC-30 = C+ 30 ppm of HC; 5). HC-45 = C+ 45 ppm of HC; 6). $\mathrm{HC}-60=\mathrm{C}+60 \mathrm{ppm}$ of $\mathrm{HC}$. Data obtained were analyzed using analysis of variance. $\mathrm{HC}$ supplementation reduced total gas, methane and protozoa count but increased the DMD, OMD, VFA. HC supplementation greater than $30 \mathrm{ppm}$ did not further improve ruminal fermentation. Supplementation at $30 \mathrm{ppm}$ of HCto dairy cow feed was the appropriate level to improve the efficiency of rumen fermentation.
\end{abstract}

Key words : heit-chrose, ruminal fermentation, dairy cattle

Abstrak. Tujuan dari penelitian ini adalah untuk mengevaluasi efek suplementasi Heit-Chrose (HC) pada fermentasi rumen sapi perah secara in vitro. $\mathrm{HC}$ merupakan suplemen pakan yang berasal dari ekstrak bawang yang mengandung allicin, saponin dan mineral organik ( $\mathrm{Se}, \mathrm{Cr}$ dan $\mathrm{Zn}$ ). Penelitian ini dilakukan dengan menggunakan rancangan acak lengkap, dengan 6 perlakuan dan 4 ulangan. Perlakuan yang dicobakan adalah: 1). $C=$ pakan sapi perah (PK 15,38\%, SK 23,38\%, TDN 61,26\%); 2 ). HC-0 = C + mineral organik (0,3 ppm Se + 0,15 ppm $\mathrm{Cr}+40$ ppm Zinc-lysinat) +0 ppm HC; 3). HC-15 = C + 15 ppm HC; 4). HC-30 = C + 30 ppm HC; 5). HC$45=\mathrm{C}+45 \mathrm{ppm} \mathrm{HC} ; 6)$. HC-60 $=\mathrm{C}+60 \mathrm{ppm} \mathrm{HC}$. Data yang diperoleh dianalisis menggunakan analisis variansi. Suplementasi HC pada fermentasi rumen sapi perah menurunkan total gas, gas metan dan jumlah protozoa serta meningkatkan kecernaan bahan kering, bahan organik dan produksi VFA, tetapi meningkatkan KBK, KBO, dan VFA. Suplementasi HC lebih besar dari $30 \mathrm{ppm}$ tidak meningkatkan fermentasi rumen. Suplementasi 30 ppm HC pada pakan sapi perah merupakan level yang optimal untuk meningkatkan efisiensi fermentasi rumen.

Kata kunci : heit-chrose, fermentasi rumen, sapi perah

\section{Introduction}

The aims of manipulation rumen ecosystem areto improve the crude fiberdigestibility in feed, reduce methane production and nitrogen excretion by ruminants. This is done to improve performance and as the most important goal of animal nutritionists (Patra et al., 2006). Extracts of plants with high concentrations of metabolites are the best way to achieve one or more of these goals (Teferedegne, 2000; Wanapat et al., 2008; Prayitno et al., 2013; Bunglavan et al., 2014). Garlic has the complete content such as allicin $\left(\mathrm{C}_{6} \mathrm{H}_{10} \mathrm{~S}_{20}\right)$, diallyl sulfide
$\left(\mathrm{C}_{6} \mathrm{H}_{10} \mathrm{~S}\right)$, diallyl disulfide $\left(\mathrm{C}_{6} \mathrm{H}_{10} \mathrm{~S}_{2}\right)$, allyl mercaptan $\left(\mathrm{C}_{3} \mathrm{H}_{6} \mathrm{~S}\right)$ and other components (Lawson, 1996), 20.13\% saponin (Prayitno et al., 2013). These components can manipulate rumen fermentation such as reducing the proportion of acetate and propionate and increasing butyrate, as inhibitors of methanogenesis and lowering the ratio of $\mathrm{CH}_{4}$ : VFA (Busquet et al., 2005; Prayitno et al., 2014). Kim et al. (2009) reported that garlic peel had a 7-fold polyphenol content than that of garlic bulbs, among others, allicin, which plays role in the decline of methanogens. Feed fermentation in the rumen will result in a decreased 
availability of mineral (Prayitno and Widiyastuti, 2010). Micro minerals such as Selenium, Chromium, and Zinc can improve the efficiency of rumen fermentation (Prayitno et al., 2013; Jayanegara et al., 2013 ). Selenium supplementation of $0.3 \mathrm{ppm}+1.5 \mathrm{ppm}$ of Chromium $+40 \mathrm{ppm}$ of Zinc in dairy cattle feed improve feed efficiency although methanogens that are formed are still in the level of $25.4 \mathrm{mM}$ (Prayitno and Widiyastuti, 2010). The purpose of this study was to assess the effect of supplementation with Heit Chrose in dairy cattle feed on the efficiency of in vitro rumen fermentation.

\section{Materials and Method}

The experiment was conducted using a completely randomized design (CRD), with 6 treatments and 4 replications. Feed consisting of $60 \%$ forage (Elephant grass $95 \%$ and $5 \%$ Gliricidia leaves) and concentrate ( coconut meal, soybean meal, pollard, cassava, minerals, CGF (Corn Gluten Feed), and CGM (Corn Gluten Meal). Feed formulation showed in Table 1.

Forage was sun dried then mashed. The research was conducted experimentally using in vitro method of Tilley and Terry (1963). Inoculum source taken from dairy cows, via mouth. The tested treatments were Control : dairy cow feed (15.38\% CP; $23.38 \%$ CF; $61.26 \%$ TDN); HC-0 : Control + organic minerals ( 0.3 ppm of Selenium +1.5 ppm of Chromium +40 ppm of Zinc- lysinat ) +0 ppm of HC; HC-15 :
Control +15 ppm of $\mathrm{HC}$; HC-30: Control +30 ppm of HC; HC-45: Control + 45 ppm of HC; HC60 : Control + organic mineral+ $60 \mathrm{ppm}$ of $\mathrm{HC}$. The data were analyzed using analysis of variance (Anova) followed by Honestly Significant Difference (HSD) test (Steel and Torrie, 1995). The variables measured were digestibility of dry matter (DMD), digestibility of organic matter (OMD), VFA, $\mathrm{NH}_{3}$, total gas (Menke and Steingass, 1988), methane (determined by $\mathrm{CO}_{2}$ trapping method according to Tjandraatmadja, 1981), the population of bacteria and protozoa (Ogimoto and Imai, 1981) and NDF digestibility. Measuring methane gas (Candraatmadja, 1981) : (1). The apparatus were arranged to form connector system T; (2) gas was taken using syringe; (3) gas in syringe was injected to the tube that was serially connected and contained $5 \mathrm{M} \mathrm{NaOH}$; (3) then the escape gas was collected in the second volume-measuring syringe to contain $\mathrm{CH}_{4}$ gas.

\section{Results and Discussions}

The results showed that there was a highly significant effect $\quad(P<0.01)$ of the supplementation treatments on the DMD and the OMD. The results of the study are shown in Table 1 . The value of dry matter and organic matter can be used as an indicator of the ease of feeding the digestibility either degradation by rumen microbes or by digestive enzymes and pascarumen digestion. The higher the DMD and the OMD, and the

Table 1. Feed composition of ration experiment (DM Basis)

\begin{tabular}{|c|c|c|c|c|c|c|}
\hline Feedstuff & C & HC-0 & HC-15 & $\mathrm{HC}-30$ & HC-30 & HC-60 \\
\hline Forage (\%) & 60 & 60 & 60 & 60 & 60 & 60 \\
\hline Concentrate (\%) & 40 & 40 & 40 & 40 & 40 & 40 \\
\hline Heit -Chrose & - & 0 & 15 & 30 & 45 & 60 \\
\hline Se organic (ppm) & - & 0.3 & & & & \\
\hline Cr organic (ppm) & - & 1.5 & & & & \\
\hline Zn-lysinate (ppm) & - & 40 & & & & \\
\hline \multicolumn{7}{|l|}{ Nutrient } \\
\hline DM (\%) & 88.41 & 88.06 & 88.23 & 88.05 & 88.34 & 88.53 \\
\hline CF (\%) & 23.38 & 23.42 & 23.52 & 23.61 & 23.49 & 23.24 \\
\hline CP (\%) & 15.38 & 15.41 & 15.39 & 15.33 & 15.52 & 15.46 \\
\hline TDN (\%) & 61.26 & 60.98 & 61.34 & 61.43 & 61.59 & 61.04 \\
\hline
\end{tabular}


higher the chances of nutrients that can be used both for livestock production and other activities. This study showed that supplementation with $\mathrm{HC}$ was able to improve rumen microbial activity. Compared to previous studies, the value of dry matter and organic matter of this study was low (Prayitno and Hidayat, 2013 ) .

\section{Total VFA}

The results showed that there was a highly significant effect $(P<0.01)$ of the treatment. The mean concentration of Volatile Fatty Acids (VFA) in total treatment feed ranged between 132-209 mM. The value exceeded adequacy of VFA as states by Kellems and Church (2010) that the sufficient range of VFA concentration for rumen microbial growth is $80-160 \mathrm{mM}$. Supplementation of $\mathrm{HC}$ in the substrate significantly affected the concentration of total VFA through increased DMD and DMO so there was more dietary available nutrients to be converted into $C_{2}$ (acetate), $C_{3}$ (propionate), and $\mathrm{C}_{4}$ (butyrate) through the process of carbohydrate metabolism. Kellems and Church (2010) stated that the VFA is the most important source of metabolic energy for ruminants and the source of the carbon chain for microbial synthesis because VFA is able to supply $55-60 \%$ of the energy needed by cattle.

This study showed HC supplementation increased the production of VFA, or manipulated the fermentation process to increase efficiency. VFA production increase occurred with supplementation of $30 \mathrm{ppm}$ of HC. VFA production is reflected the process of carbohydrates fermentation and related to the productivity of livestock because most of the VFA in the rumen derived from the fermentation of feed carbohydrate (Hungate, 1966). Ration HC-30 had the highest total VFA, this treatment was thought to contain nonstructural carbohydrate (starch) more than the other treatments to contribute to the fermentation of feed, resulting in higher VFA production. Jouany (1994) stated that the nonstructural carbohydrates contribute VFA production that is higher than structural carbohydrates.

The results showed that the treatment affected $(P<0.05)$ the concentration of ammonia. It showed that supplementation of $\mathrm{HC}$ in the dairy affected microbial activity in the rumen metabolism of proteins to produce ammonia. The average concentrations of ammonia ranged from $13-16 \mathrm{mM}$. The values exceeded the adequacy of ammonia concentration in the rumen. One of the causes high concentrations of $\mathrm{NH}_{3}$ was no absorption of ammonia in an in vitro systems resulting in the accumulation of ammonia in the syringe. There was residual ammonia which was not used in the synthesis of microbial protein together with the carbon skeleton derived from the fermentation of carbohydrates, and also could be from donations of protein lysis from microbes. The results in Table 2 show that the average values of ammonia on the successive treatments were $14.72 \pm 1.652 \mathrm{mM}$ (HC-0), $14.20 \pm 1.000 \mathrm{mM}$ (HC-15), $13.02 \pm 1.579 \mathrm{mM}$ (HC$30), 16.88 \pm 1.439 \mathrm{mM}$ (HC-45), $15.58 \pm 1.895 \mathrm{mM}$ (HC-60). Kurniawati (2009) observed the concentration of $\mathrm{NH}_{3}$ generated from all treatments with the addition of Lerak extracts (Sapindus rarak) ranged between 15.85 to $16.31 \mathrm{mM}$ and the values were still optimal for rumen microbial growth. The $\mathrm{NH}_{3}$ concentration of less than $3.57 \mathrm{mM}$ may inhibit rumen microbial growth (McDonald et al., 1995).

\section{NDF digestibility}

The results showed a decline in NDF digestibility significantly $(P<0.01)$ in Table 1 . NDF digestibility in this study ranged between $29.43-36.58 \%$. NDF digestibility was highest in the treatment of HC-15 amounted to $36.58 \%$ and the lowest for the treatment NDF digestibility HC-60 amounted to $29.43 \%$. 
Table 2. The Effects of HC supplementation on DMD, OMD, total VFA, NH3 and NDF digestibility

\begin{tabular}{lrrrrrr}
\hline Parameter & \multicolumn{1}{c}{$\mathrm{C}$} & \multicolumn{1}{c}{$\mathrm{HC}-0$} & \multicolumn{1}{c}{$\mathrm{HC}-15$} & \multicolumn{1}{c}{$\mathrm{HC}-30$} & \multicolumn{1}{c}{$\mathrm{HC}-45$} & $\mathrm{HC}-60$ \\
\hline DMD $(\%)$ & $34.09 \pm 1.7^{\mathrm{a}}$ & $37.85 \pm 1.58^{\mathrm{abc}}$ & $39.32 \pm 2.59^{\mathrm{c}}$ & $34.13 \pm 1.43^{\mathrm{ab}}$ & $35.5 \pm 0.57^{\mathrm{abc}}$ & $35.48 \pm 2.10^{\mathrm{abc}}$ \\
OMD (\%) & $32.02 \pm 1.45^{\mathrm{a}}$ & $35.57 \pm 2.01^{\mathrm{abc}}$ & $37.22 \pm 0.93^{\mathrm{c}}$ & $32.05 \pm 4.03^{\mathrm{ab}}$ & $33.4 \pm 2.09^{\mathrm{abc}}$ & $33.28 \pm 0.75^{\mathrm{abc}}$ \\
NDFD (\%) & $31.33 \pm 2.14^{\mathrm{ab}}$ & $34.71 \pm 2.12^{\mathrm{ab}}$ & $36.58 \pm 2.01^{\mathrm{b}}$ & $31.67 \pm 0.76^{\mathrm{ab}}$ & $31.12 \pm 2.84^{\mathrm{ab}}$ & $29.43 \pm 1.46^{\mathrm{a}}$ \\
pH & $7 \pm 0.00^{\mathrm{b}}$ & $7 \pm 0.00^{\mathrm{b}}$ & $6.9 \pm 0.00^{\mathrm{a}}$ & $6.97 \pm 0.06^{\mathrm{b}}$ & $7 \pm 0.00^{\mathrm{b}}$ & $7 \pm 0.00^{\mathrm{b}}$ \\
Total VFA & $147.5 \pm 24.24^{\mathrm{ab}}$ & $165 \pm 6.00^{\mathrm{abc}}$ & $180.5 \pm 12.26^{\mathrm{bcd}}$ & $209 \pm 24.30^{\mathrm{bd}}$ & $174.5 \pm 12.15^{\mathrm{bcd}}$ & $132 \pm 9.93^{\mathrm{a}}$ \\
Amonia mM & $14.68 \pm 1.59$ & $14.72 \pm 1.652$ & $14.20 \pm 1.00$ & $13.20 \pm 1.579$ & $16.88 \pm 1.439$ & $15.58 \pm 1.895$ \\
\hline
\end{tabular}

Values bearing same superscript in one row are not significantly different $(P>0.05)$

The high digestibility of NDF in the treatment of R2 assumed to be was due to the ability of the rumen microbes to degrade the fiber fraction. This study showed that supplementations of dairy cows feed with $\mathrm{HC}$ to the extent of 30 ppm were able to increase the efficiency of rumen fermentation. This condition occured presumably because of the increased rumen microbial activity and decreased production of $\mathrm{CH} 4$. Heit-Chrose with active ingredient of allicin and saponins and $\mathrm{Se}, \mathrm{Cr}$, and $\mathrm{Zn}$ minerals allegedly was able to improve rumen fermentation. The results of this study showed that increasing levels Chrose Heit will lower crude fiber digestibility. The decline in crude fiber alleged suppression of the activity of cellulolytic rumen bacteria.

\section{Total gas}

The results showed that supplementation of Heit-Chrose affected rumen fermentation of liquid phase when the feed of dairy cows substrate contained adequate organic minerals. Gas production varied and (tended to be lower) than in control (HC-O and HC-15) (Table2). The highest gas production occurred in HC-60 treatment. The total gas was a result of fermented feed, especially organic materials into VFA performed by rumen microbes. The amount of gas produced showed high or low digestibility of the feed. High production of gas indicated inefficiency usage of feed, thereby, increased the gas production. The little amount of gas produced in this study showed that fermented organic materials were used for microbial protein synthesis (Kellems and Church
(2010). Gas resulted from rumen fermentation consisted of $\mathrm{CO}_{2}, \mathrm{~N}_{2}, \mathrm{H}_{2}$ and $\mathrm{CH}_{4}$.

\section{Methane}

Result showed that Heit-Chrose supplementation in dairy cow feed affected the concentration of methane gas, by decreasing $20-25 \%$ methane gas. This study shows that supplementation Heit-Chrose on feed dairy cows affected the concentration of methane gas. Supplementation Heit-Chrose was able to decrease methane gas between 20 and 50\%. The most significant decrease was reached at $30 \mathrm{ppm}$ Heit-Chrose at certain percentage, while $60 \mathrm{ppm}$ Heit-Chrose did not affect the concentration of methane gas. The result also indicated that the active substance in HeitChrose was effective to limit methanogen performance, thereby slowing down methane production. It was reported that allicin extracted from garlic could function more effectively than that from plant (Busquet et al., 2007). In ruminants, the $\mathrm{H}_{2}$ is normally removed by the reduction of $\mathrm{CO}_{2}$ to form methane. Silivong et al. (2013) stated that the longer incubation time would increase methane gas concentration at 24-hour incubation. Methane gas concentration decreased as the nitrate was increased from $52.0 \mathrm{ml} / \mathrm{g}$ to 15.6 $\mathrm{ml} / \mathrm{g}$.

\section{Protozoa population}

Protozoa population in these treatments had varied values and tended to be lower than the control, except for R2. This indicated that the saponins in HC (20.13\%) could break down the cell membrane of protozoa (Prayitno et al., 2013). On the other hand, the HC could inhibit 
the formation of methane, which was of allicin origin that inhibited the enzyme, HMG-CoA reductase (Busquet et al., 2005). As a result, the availability of $\mathrm{H}_{2}$ in the rumen was not used for the synthesis of methane, but for the synthesis of propionate (Prayitno et al., 2013).

The results of analysis of variance showed that the treatment affected highly significantly ( $P<0.01)$ on the protozoa population. The highest average value on protozoa population was reached by the control feed (C) is $2.05 \pm$ $0.50\left(10^{6}\right.$ cells $/ \mathrm{ml}$ rumen fluid) and the lowest average was achieved by control feed $+15 \mathrm{ppm}$ of HC (HC-15),0.94 $\pm 0.423\left(10^{6} \mathrm{cells} / \mathrm{ml}\right.$ rumen fluid). Protozoa population declined due to reduced population of methanogens that are symbiotic with protozoa due to saponins and allicin role of HC. Kongmun et al. (2011) adds, the saponin contained in the flour of garlic oil can reduce methane bacteria, therefore, the protozoa population decreases. Research result informed that increasing Heit-Chrose supplement was not linear with the decreasing protozoa population. Relation between protozoa population and total gas is presented in Figure 1. Previous research on garlic powder supplement to beef cattle feed which based on ammoniated paddy straw reported the decreasing protozoa population up to $48 \%$ (Prayitno and Hidayat, 2013).

\section{Total bacteria}

The results showed that the treatment affected highly significantly $(P<0.01)$ on total rumen bacteria. Increased total rumen bacteria presumably because of the feed treatment that

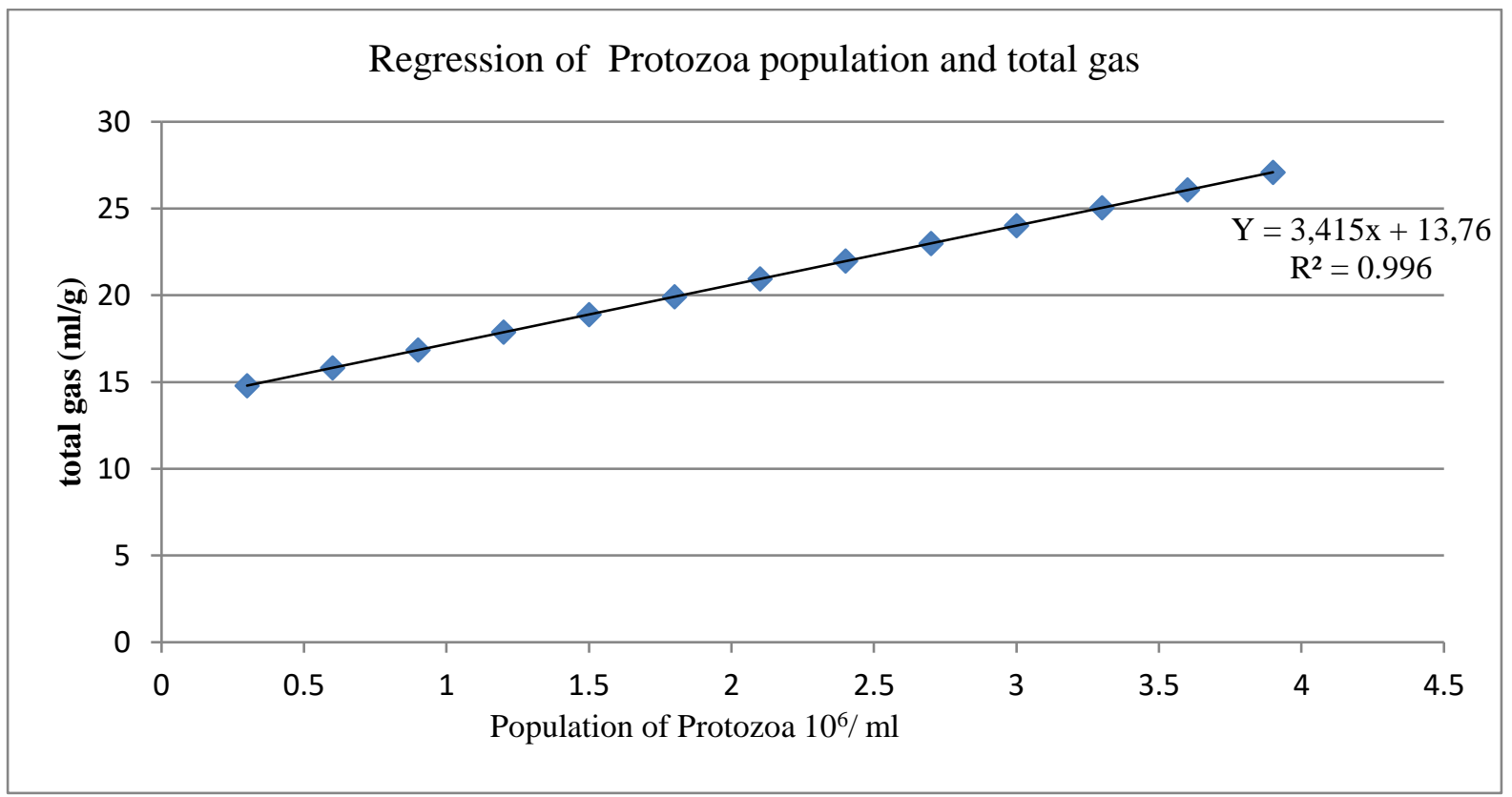

Figure 1. Relationship between Protozoa Population and Production of Total Gas

Table 3. The effects of HC supplementation on gas total, methane, protozoa count and bacterial

\begin{tabular}{lcccccc}
\hline Parameter & $\mathrm{C}$ & $\mathrm{HC}-0$ & $\mathrm{HC}-15$ & HC-30 & HC-45 & HC-60 \\
\hline Gas Total & $27.71 \pm 3.68^{\mathrm{c}}$ & $24.28 \pm 2.13^{\mathrm{abc}}$ & $22.48 \pm 1.21^{\mathrm{abc}}$ & $21.06 \pm 2.04^{\mathrm{a}}$ & $21.63 \pm 5.58^{\mathrm{ab}}$ & $24.34 \pm 1.6^{\mathrm{abc}}$ \\
(ml/mg) & $13.11 \pm 1.03^{\mathrm{c}}$ & $13.34 \pm 1.39^{\mathrm{c}}$ & $11.92 \pm 1.42^{\mathrm{b}}$ & $6.35 \pm 1.11^{\mathrm{a}}$ & $8.04 \pm 1.96^{\mathrm{ab}}$ & $12.09 \pm 1.63^{\mathrm{b}}$ \\
Methane gas (ml/mg) & $2.05 \pm 0.503^{\mathrm{b}}$ & $1.46 \pm 0.498^{\mathrm{ab}}$ & $0.94 \pm 0.423^{\mathrm{a}}$ & $1.18 \pm 0.323^{\mathrm{ab}}$ & $1.35 \pm 0.270^{\mathrm{ab}}$ & $1.34 \pm 0.518^{\mathrm{ab}}$ \\
Protozoa (106/ml) & $10.28 \pm 0.119$ & $10.24 \pm 0.106$ & $10.32 \pm 0.103$ & $10.39 \pm 0.122$ & $10.52 \pm 0.044$ & $10.50 \pm 0.112$ \\
\hline \multicolumn{7}{l}{ Bacteria (log 10/0.05g DM) } \\
Values bearing same superscript letter(s) in the same row are not significantly different (P>0.05)
\end{tabular}


was capable of providing nutrients for the growth of the microbes. In addition, it could be affected by the presence of declined protozoa population due to inhibition of methanogenic activity that wasin symbiotic with protozoa (Newbold et al., 1995). The average values of total bacteria ranged from 10.32 to 10.52 (log 10/0.05 gr DM). The mean of total bacteria from all treatments was shown in Table 1. Based on Table 1, treatment HC-60 with a level of $60 \mathrm{ppm}$ of $\mathrm{HC}$ had a value of highest total bacteria, thus the active ingredient in allicin and organosulfur of garlic efficiently inhibited the performance of the enzyme of HMG - CoA in suppressing the methanogenic population, so that feed was used more efficiently and total rumen bacteria increased. A research by Kongmun et al. (2011) showed administration of 50 grams of garlic powder on buffaloes were able to increase the total cellulolytic bacteria by $42.2 \%$ in the 4 -hour observation. The increase of fiber degrading bacteria population will result in an increase in rumen fermentation products. The increasing population of microbes in the rumen will increase the amount of microbial protein.

\section{Conclusions}

Heit-Chrose supplementation in feed of dairy cows by in vitro is able to increase the efficiency of rumen fermentation, as indicated by the increasing feed digestibility, VFA and decreasing total gas production, methane gas and protozoa populations.

\section{References}

Anassori E, B Dalir-Naghadeh, B Pirmohammadi, A Taghizadeh, S Asri-Rezaei, S Farahmand-Azar, M Besharati and M Tahmoozi. 2012. In vitro assesment of digestibility of forage based sheep diet, supplemented with raw garlic, garlic oil and monensin. Vet. Res. Forum. 3:5-11.

Bunglavan SJ. 2014. Methanogenesis and recent techniques for mitigation of methanogenesis in ruminants. Livestock Sci. 5:35-48.
Busquet M, S Calsamiglia, A Ferret, C Kamel and W Cardozo. 2006. Plant extracts affect in vitro rumen microbial fermentation. J. Dairy Sci. 89: 761-771.

Busquet M, S Calsamiglia, A Ferret, MD Carro and C Kamel. 2005. Effect of garlic oil and four of its compounds on rumen microbial fermentation. J. Dairy Sci. 88:4393-4404.

Bodas R, S Lopez, M Fernandez, R Garcia-Gonzalez, A B Rodriguez, R J Wallace and J. S. Gonzalez. 2008. In vitro screening of the potential of numerous plant species as antimethanogenic feed additives for ruminants. Anim. Feed Sci. Technol. 145:245258.

Eugene M, H Archimede, B Michalet-Doreau and G Fonty. 2004. Effect of defaunation on microbial activities in the rumen of rams consuming a mixed diet (fresh Digitaria decumbens grass and concentrate). Anim. Res.53:187-200.

Frankic T, M Voljc, J Salobir and V Rezar. 2009. Use of herbs and speces and their extracts in animal nutrition. Acta argiculturae Slovenica. 94:95-102.

Ghosh S, RK Mehla, SK Sirohi and SK Tomar. 2011. Performance of crossbred calves with dietary supplementation of garlic extract. J. Animal Physiology and Animal Nutrition. 95:449-455.

Guo YQ, J-X Liu, Y Lu, WY Zhu, SE Denman and CS McSweeney. 2008. Effect of tea saponin on methanogenesis, microbial community structure and expression of mcrA gene, incultures of rumen micro-organisms. J.Compilation47: 421426.

Hungate RE. 1966. The Ruminant and It's Microbes. Agricultural Experimental Station, University of California. Academic Press. New York, San Fransisco, London. p. 197

Jayanegara A, AS Tjakradidjaja and T Sutardi. 2006. Fermentabilities and digestibility of byproduct agroindustry with supplemented organic and anorganicchromium.Media Peternakan. 29: 5462.

Jouany JP. 1994. Rumen Microbial Metabolismand Ruminant Digestion. Institut National deLa Recherce Agronomique Edition. Paris. p.165 178.

Khalesizadeh A, A Vakili, MD Mesgaran and R. Valizadeh. 2011. The Effect of garlic Oil (Allium sativa), Turmeric Powder (Curcuma longa Linn) and Monensin on Total Apparent Digestibility of Nutrients in Balloochi Lambs. World Academy of Science, Engineering and Technology 59 : 2065.

Kellems RO and DC Chruch. 2010. Livestock Feeds and Feeding. Prentice Hall. New York.

Kim YJ, SK Jin and HS Yang. 2009. Processing, products, and food safety: Effect of dietary garlic bulb and husk on the physicochemical properties of chicken meat. Poultry Sci. 88 : $398-405$. 
Kongmun $\mathrm{P}, \mathrm{M}$ Wanapat, $\mathrm{P}$ Pakdee and C Navanukraw. 2010. Effect of Coconut Oil and Garlic Powder On In Vitro Fermentation Using Gas Production Technique. Livest. Sci. 127 : 3844.

Kongmun P, M Wanapat, P Pakdee, C Navanukraw and Z Yu. 2011. Manipulation of rumen fermentation and ecology of swamp buffalo by coconut oil and garlic powder supplementation. Livestock Sci. 135 : 84-92.

Lawson L. 1996. The composition and chemistry of garlic cloves and liquor of buffalo. Anim. Feed Sci. Technol. 128, 276-291.

Martin C, DP Morgavi and M Doreau. 2010. Methane mitigation in ruminants : from microbe to the farm scale. Animal. 4:351-365.

McDonald P, RA Edwards, JED Greenhalgh and CA Morgan. 1995. Animal Nutrition. 5th Ed. Prentice Hall. USA.

Menke A and A Steingass. 1988. Estimation of the energetic feed value obtained from chemical analysis and gas production using rumen fluid. Anim.Res.Dev.28: 7-55.

Morgavi DP, E Ferano, C Martin and CJ Newbold. 2010. Microbial ecosystem and methanogenesis in ruminants. Animal. 4: 1024-1036.

Newbold CJ, B Lassalas and JP Jounay. 1995. The importance of methanogens associated with ciliateprotozoa in ruminal methane production in vitro. Letters in Applied Microbiology.4:230-234.

Ogimoto Kand S Imai. 1981. Atlas of Rumen Microbiology. Japan Science. Societes Press, Tokyo.

Patra AK, DN Kamra and N Agarwal. 2006. Effect of plant extracts on in vitro methanogenesis, enzyme activities and fermentation of feed in rumen liquor of buffalo. Anim. Feed Sci. Technol. 128: $276-291$
Prayitno $\mathrm{CH}$ and T Widiyastuti. 2010. The study of selenomethionin, Chromium Yeast and zinc proteinate on dairy cow feed (Review in vitro). In Proceedings of the seminar national : Perpective development of agribusiness. Faculty of Animal Science, Jenderal Soedirman University. Purwokerto (In Indonesia).

Prayitno CH, Y Subagyo and Suwarno. 2013. Supplementation of Sapindus rarak and garlic extract in feed containing adequate $\mathrm{Cr}$, Se, and $\mathrm{Zn}$ on rumen fermentation. Media Peternakan. $36: 52-57$.

Silivong P, B Hervaseng and TR Preston. 2013. Methane production from Jack fruit, Muntingia, Leucaena, Gliricidia (Gliricidiasepium), Mimosa (Mimosa pigra) and Acasiaauriculoformisfoliages in an in vitro incubation with potassium nitrate as source of NPN. Livestock Res. Rur. Develop. 25:1-5.

Steel RGD and JH Torrie. 1995. Principles and Procedure of Statistic. A Biometrical Approach. $2^{\text {nd }}$ Ed. McGraw Hill International Book Co., London.

Teferedegne B. 2000. New perspectives on the use of tropical plants toimprove ruminant nutrition. Proc. Nutr. Soc. 59: 209-214.

Tilley JMA and RA Terry. 1963. A two stage technique for the in vitro digestion of forage. J. British Grassland Soc.18:104-111.

Tjandraatmadja M. 1981. Anaerobic Digestion of Fibrous Materials.A Thesis of Master of Agricultural Science. University of Melbourne, Australia.

Wanapat $M$, A Cherdthong, $P$ Pakdee and S Wanapat. 2008. Manipulation of rumen ecology by dietary lemongrass (Cymbopogon citratus Stapf.) powder supplementation. J. Anim. Sci. 86 :3497-3503. 